\title{
Lack of modifying potential of 8-methoxypsoralen in the promotion or progression stages of lung carcinogenesis in $\mathbf{A} / \mathbf{J}$ female mice
}

\author{
TOSHIYA KUNO, MASANAO YOKOHIRA, YOKO MATSUDA, SATOSHI SUZUKI, \\ NOZOMI HASHIMOTO, KEIKO YAMAKAWA, KOUSUKE SAOO and KATSUMI IMAIDA \\ Onco-Pathology, Department of Pathology and Host-Defence, \\ Faculty of Medicine, Kagawa University, Kita-gun, Kagawa 761-0793, Japan
}

Received May 7, 2008; Accepted June 12, 2008

DOI: 10.3892/or_00000072

\begin{abstract}
Pretreatment with 8-methoxypsoralen (8-MOP), a potent human CYP2A6 inhibitor, strongly suppresses lung tumorigenesis by 4-(methylnitrosamino)-1-(3-pyridyl)-1butanone (NNK) in female A/J mice. Since it has been reported that CYP2A protein is highly expressed in NNKinduced lung adenomas and adenocarcinomas, potential anticancer properties of 8 -MOP in female $\mathrm{A} / \mathrm{J}$ mice were examined subsequent to initiation. The agent was administered at $100 \mathrm{ppm}$ levels in the diet during the promotion phase (experimental weeks 1-16) and progression phase (experimental weeks 16-32) and mice were sacrificed for histopathological examination of lung tumor development at 16 and 32 weeks after the initiation of NNK treatment $(2 \mathrm{mg} /$ $0.1 \mathrm{ml}$ saline/mouse, i.p.), respectively. Chemopreventive effects of 8-MOP were not observed in either experiment. In addition, no modifying effects on hepatic mRNA levels for CYP2A5, considered to be the mouse ortholog of human CYP2A6, were evident. On immunohistochemical analysis, the CYP2A protein was found to be overexpressed in all lung adenomas and adenocarcinomas, with or without 8-MOP. It can be concluded from the present data that $8-\mathrm{MOP}$ at $100 \mathrm{ppm}$ in the diet does not prevent mouse lung carcinogenesis when administered in the post-initiation phase.
\end{abstract}

\section{Introduction}

Lung cancer is one of the most common causes of cancer mortality in the world, with cigarette smoking generally

Correspondence to: Dr Toshiya Kuno, Onco-Pathology, Department of Pathology and Host-Defence, Faculty of Medicine, Kagawa University, Kita-gun, Kagawa 761-0793, Japan

E-mail:kuno@med.kagawa-u.ac.jp

Abbreviations: NNK, 4-(methylnitrosamino)-1-(3-pyridyl)-1butanone; 8-MOP, 8-methoxypsoralen; CYP, cytochrome P450

Key words: lung tumor, 8-methoxypsoralen, post-initiation regarded as the most important risk factor (1). Tobacco smoking increases the risk of all major histological types of lung cancer (2). The association between lung adenocarcinoma and smoking has become stronger over time and adenocarcinoma has become the most common type in many Western countries (3). Among the tobacco smoke components, 4-(methylnitrosamino)-1-(3-pyridyl)-1-butanone (NNK), a tobacco-specific $\mathrm{N}$-nitrosamine, is thought to play a critical role of in the causation of lung cancer in smokers, since it primarily induces lung tumors in laboratory animals (4). Especially, the $\mathrm{A} / \mathrm{J}$ mouse is sensitive and the lung lesions induced by NNK can be histopathologically classified as adenocarcinomas, adenomas, and alveolar cell hyperplasias, generally similar to human lung tumors. The A/J mouse is a very reliable strain as an in vivo model, which can be used for detecting chemopreventive agents active against lung carcinogenesis (5).

Most environmental chemical carcinogens are metabolized by phase I and phase II enzymes to exert their biological effects through formation of DNA adducts. Cytochrome P450 (CYP), the major family of phase I enzymes, is responsible for metabolic activation of carcinogens. CYP2A6 is well known to metabolize tobacco-specific nitrosamines, as well as counterparts in the diet (6). Several polymorphisms of the CYP2A6 gene have been identified to date and shown to have associations with lung cancer risk. For example, Japanese male smokers with a CYP2A6 gene deletion-type polymorphism were demonstrated to be at reduced lung cancer risk in a hospital-based case control study $(7,8)$.

Previously, we revealed that human lung and colorectal carcinomas express CYP2A6 and that up-regulation may occur in cases with high malignant potential $(9,10)$. Our earlier experiments also demonstrated that pretreatment with 8-methoxypsoralen (8-MOP), a potent human CYP2A6 inhibitor, strongly inhibits mouse lung tumorigenesis by NNK in a dose-dependent manner $(11,12)$. Since aberrant expression of a protein cross-reactive to antibodies to CYP2A1 can also be clearly seen in NNK-induced mouse lung adenomas and adenocarcinomas (13), CYP2A6 might be a molecular target for prevention of lung carcinomas. Thus, in the present investigation, we examined effects of dietary exposure to 8 -MOP during promotion and progression phases on NNKinduced lung tumorigenesis in female $\mathrm{A} / \mathrm{J}$ mice. 
Mouse CYP2A5 is a specific and efficient catalyst of coumarin 7-hydroxylation and is considered to be the mouse ortholog of human CYP2A6 (14). Determination of whether 8-MOP might influence the hepatic mRNA expression of CYP2A5 on long-term ingestion was also included in the present study.

\section{Materials and methods}

Animals and chemicals. Female 6-week old A/J mice for experiments 1 and 2 were purchased from SLC Japan (Shizuoka, Japan) and maintained in the Kagawa University Animal Facility according to the institutional animal care guidelines. All of the animals were housed in polycarbonate cages with wire wood chips for bedding, and given free access to drinking water and a basal diet, Oriental MF (Oriental Yeast Co., Ltd., Tokyo, Japan), under controlled conditions of humidity $(60 \pm 10 \%)$, lighting (12 h light/dark cycle), and temperature $\left(24 \pm 2^{\circ} \mathrm{C}\right)$. After a 1 -week acclimation period, the animals were used in the experiments. 8-MOP was purchased from Sigma (St. Louis, MO) and NNK from Toronto Research Chemicals (Ontario, Canada). 8-MOP was mixed with Oriental MF powdered basal diet at a $100 \mathrm{ppm}$ concentration and stored at $4^{\circ} \mathrm{C}$ in the dark before use. Food in food containers was replaced once a week. The doses of 8-MOP used in the present study were chosen based on the results of previous studies (11-13).

\section{Experimental procedure}

Experiment 1. For the promotion phase study, a total of 83 mice were randomized into 4 groups (Fig. 1). At 7 weeks of age, mice in groups 1 and 2 received a single dose of NNK (2 mg/ $0.1 \mathrm{ml}$ saline/mouse, i.p.), while those in groups 3 and 4 were given an equal volume of saline. Animals in groups 2 and 3, on basal diet during the carcinogen treatment, received $100 \mathrm{ppm}$ 8 -MOP in diet during the promotion phase (1 week after the NNK treatment). Mice in groups 1 and 4 were given the basal diet and tap water throughout the experimental period. Body weights were recorded weekly until the termination of the study.

Experiment 2. For the progression phase study, a total of 103 mice were randomized into 4 groups (Fig. 2). The mice in groups 1-4 were injected with NNK and saline as in experiment 1 . Starting 16 weeks after the injection of NNK, mice in groups 2 and 3 were fed the diet containing 100 ppm
Group

1. NNK alone

2. $\mathrm{NNK} \rightarrow 100 \mathrm{ppm} 8-\mathrm{MOP}$

3. $100 \mathrm{ppm} 8-\mathrm{MOP}$

4. Basal diet

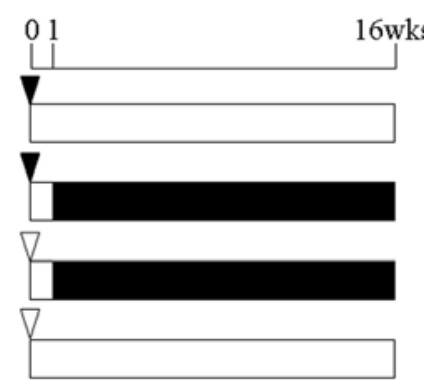

Figure 1. Experimental protocols for Experiments 1 and 2. Animals were 7-week-old female A/J mice. $\square, 8$-MOP (100 ppm); $\square$, basal diet (oriental MF); black arrowhead, NNK (2 mg/mouse, i.p.); white arrowhead, saline (0.1 ml/mouse, i.p.).

8-MOP until the termination. Mice in groups 1 and 4 were given the basal diet throughout the experiment.

Experiments 1 and 2 were terminated 16 and 32 weeks after the start, respectively. Surviving animals were sacrificed under ether anesthesia and their lungs, livers and kidneys were excised and weighed. The lungs were infused through the bronchi with $10 \%$ neutral-buffered formalin and carefully inspected grossly using a stereomicroscope for macroscopic tumor counting. Lung nodules were excised under a microscope. All tissues were routinely processed for embedding in paraffin, serially sectioned at $4 \mu \mathrm{m}$ and stained with H\&E for histopathological examination. Lung nodules, alveolar hyperplasias, adenomas and adenocarcinomas were diagnosed according to established criteria (15).

Quantitative real-time reverse transcription-PCR. Liver tissues from each group in experiment 1 were examined for mRNA expression by quantitative real-time reverse transcriptionPCR (RT-PCR). RNA was extracted using the RNeasy Plus Mini kit (Qiagen) according to the manufacturer's protocol and cDNA was synthesized from $400 \mathrm{ng}$ of total RNA using QuantiTect Reverse Transcription (Qiagen). Real-time RTPCR was achieved with an ABI PRISM 7000 Sequence Detection System (Applied Biosystems, Foster city, CA) using specific primers and Taq Man probes for mouse CYP2A5. The expression level of the gene was normalized to the S18 rRNA expression level using the standard curve method. Experiments were performed in duplicate and then the average value was calculated. The primers for amplification were as follows: mouse CYP2A5, forward 5'-CCA ACGTTATGGTCCTGTATTCAC-3', reverse 5'-TCCACC

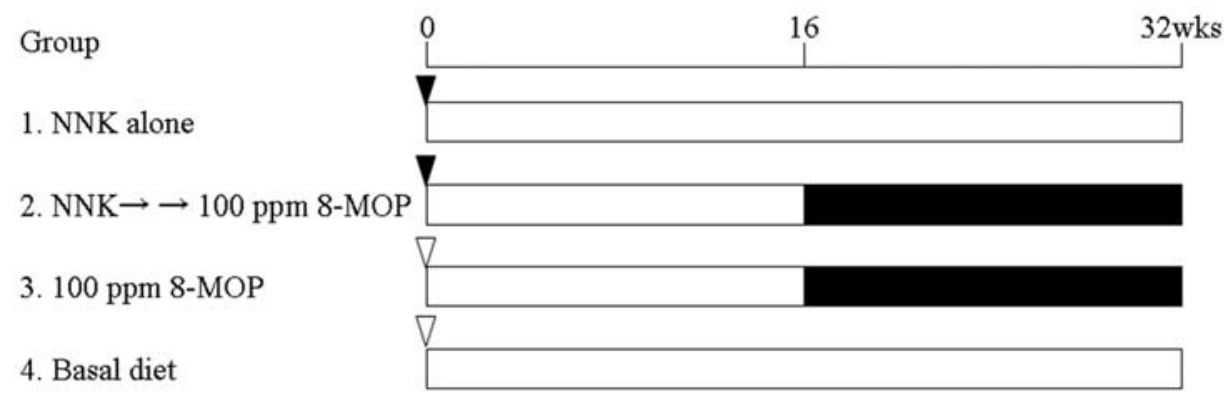

Figure 2. Experimental protocols for Experiments 1 and 2. Animals were 7-week-old female A/J mice. $\mathbf{0}, 8-\mathrm{MOP}$ (100 ppm); $\square$, basal diet (oriental MF); black arrowhead, NNK (2 mg/mouse, i.p.); white arrowhead, saline $(0.1 \mathrm{ml} / \mathrm{mouse}$, i.p.). 
Table I. Final body weights, relative organ weights and mean food intakes (Experiment 1).

\begin{tabular}{|c|c|c|c|c|c|c|c|}
\hline \multirow[b]{2}{*}{ Group } & \multirow[b]{2}{*}{ Treatment } & \multirow[b]{2}{*}{ No. mice } & \multirow[b]{2}{*}{$\begin{array}{l}\text { Final body } \\
\text { weight (g) }\end{array}$} & \multicolumn{4}{|c|}{ Relative organ weight } \\
\hline & & & & $\begin{array}{l}\text { Lung } \\
(\mathrm{g} \%)\end{array}$ & $\begin{array}{l}\text { Liver } \\
(\mathrm{g} \%)\end{array}$ & $\begin{array}{l}\text { Kidney } \\
(\mathrm{g} \%)\end{array}$ & $\begin{array}{c}\text { Mean food } \\
\text { intake ( } \mathrm{g} / \text { day) }\end{array}$ \\
\hline 1 & NNK alone & 26 & $24.34 \pm 3.06^{\mathrm{a}}$ & $0.76 \pm 0.15$ & $4.21 \pm 0.29$ & $0.96 \pm 0.09$ & $1.98 \pm 0.12$ \\
\hline 2 & NNK $\rightarrow 100$ ppm 8-MOP & 27 & $29.16 \pm 3.44^{\mathrm{b}}$ & $0.63 \pm 0.10^{\mathrm{b}}$ & $4.05 \pm 0.28$ & $0.90 \pm 0.07^{\mathrm{c}}$ & $2.59 \pm 0.05^{\mathrm{b}}$ \\
\hline 3 & 100 ppm 8-MOP & 15 & $34.48 \pm 3.83^{\mathrm{b}, \mathrm{d}}$ & $0.60 \pm 0.06^{\mathrm{b}}$ & $3.85 \pm 0.25^{b}$ & $0.88 \pm 0.07^{\mathrm{c}}$ & $3.24 \pm 0.21^{\mathrm{b}, \mathrm{d}}$ \\
\hline 4 & Basal diet & 15 & $30.74 \pm 3.58^{\mathrm{b}, \mathrm{e}}$ & $0.73 \pm 0.15^{\mathrm{e}, \mathrm{f}}$ & $4.23 \pm 0.25^{\mathrm{g}}$ & $0.94 \pm 0.11$ & $2.42 \pm 0.17^{\mathrm{b}, \mathrm{g}}$ \\
\hline
\end{tabular}

${ }^{\mathrm{a}}$ Mean $\pm \mathrm{SD}$. ${ }^{\mathrm{b}}$ Significantly different from group $1(\mathrm{P}<0.01)$. ${ }^{\mathrm{c} S i g n i f i c a n t l y ~ d i f f e r e n t ~ f r o m ~ g r o u p ~} 1(\mathrm{P}<0.05)$. ${ }^{\mathrm{d}}$ Significantly different from group $2(\mathrm{P}<0.01)$. ${ }^{\mathrm{e} S i g n i f i c a n t l y ~ d i f f e r e n t ~ f r o m ~ g r o u p ~} 3(\mathrm{P}<0.05)$. ${ }^{\mathrm{f}}$ Significantly different from group $2(\mathrm{P}<0.05)$. ${ }^{\mathrm{g}}$ Significantly different from group $3(\mathrm{P}<0.01)$.

Table II. Incidence and multiplicity of NNK-induced pathological lung lesions in A/J mice treated with 8-MOP during promotion phase.

\begin{tabular}{lcccccc}
\hline Group & Treatment & No. mice & Incidence (\%) & Hyperplasia & Adenoma & Total \\
\hline 1 & NNK alone & 26 & 65 & $0.35 \pm 0.56^{\mathrm{a}}$ & $1.19 \pm 1.86$ & $1.54 \pm 1.96$ \\
2 & NNK $\rightarrow$ 100 ppm 8-MOP & 27 & 85 & $0.70 \pm 0.87$ & $1.44 \pm 2.17$ & $2.15 \pm 2.03$ \\
3 & 100 ppm 8-MOP & 15 & 13 & $0.20 \pm 0.77$ & $0.13 \pm 0.52$ & $0.33 \pm 0.90$ \\
4 & Basal diet & 15 & 27 & $0.07 \pm 0.26$ & $0.20 \pm 0.41$ & $0.26 \pm 0.46$ \\
\hline
\end{tabular}

${ }^{\mathrm{a}}$ Mean $\pm \mathrm{SD}$.

AGAGCTTCCTTGACT-3', and probe 5'-ACAGCACCA CAATTC-3'. The sequences of primers and probes for S18 rRNA are not known because they were purchased from the Assays-demand system of ABI.

Immunohistochemistry. Lungs were immunostained for CYP2A by the ABC method, all staining processes from deparaffinization to counterstaining with hematoxylin being performed using the Ventana HX automated immunohistochemistry slide staining system (Ventana Japan, Yokohama, Japan). The primary antibody (polyclonal antirabbit CYP2A1 generously provided by Dr T. Kamataki of Hokkaido University, Sapporo, Japan) was applied for $60 \mathrm{~min}$ at room temperature at 50 -fold dilution.

Statistical analysis. All quantitative data were compared using Bonferroni's multiple comparison post-hoc test or Fisher's exact probability test. Differences were considered statistically significant at $\mathrm{P}<0.05$.

\section{Results}

Experiment 1. The mice proved fully tolerant to the NNK and 8-MOP treatments. The mean intake of food in group 3 (8-MOP alone group) was significantly greater than those of groups 1, 2 and 4 (Table I). The mean body weight gain was also largest in the same group. Compared with group 1, the final body weights were significantly greater in groups 2, 3 and 4. Inversely, relative lung, liver and kidney weights were significantly decreased in the 8-MOP alone group when

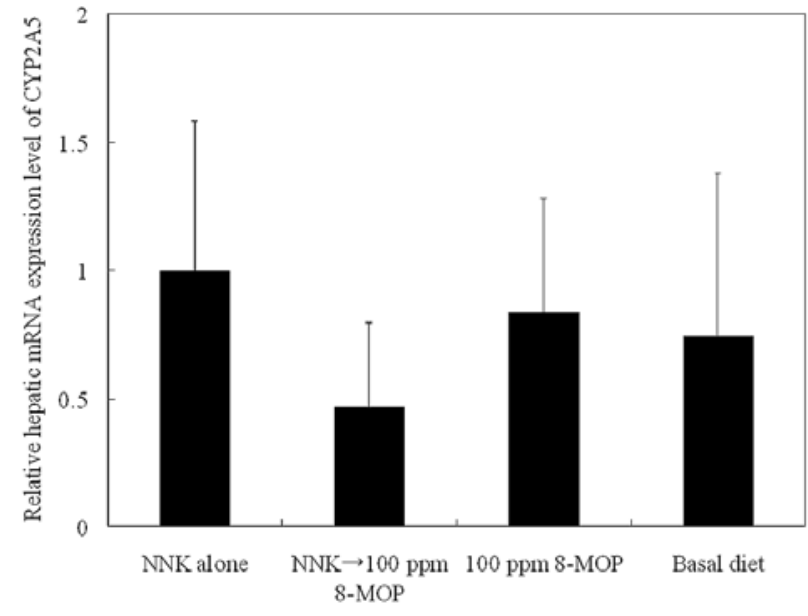

Figure 3. Relative hepatic mRNA expression levels of the CYP2A5 gene as measured by quantitative real-time RT-PCR in A/J mice. Values were normalized to S18 rRNA expression using the standard curve method. (Columns, mean of two independent experiments; Bars, SD; n=4-6).

compared with group 1, but there no other related changes, so they were considered as having no toxicological significance.

Hyperplasias and adenomas developed in the lungs of mice in all groups, as shown in Table II. Dietary feeding of 8 MOP after NNK exposure appeared to be associated with increased development of lesions, though the differences were not statistically significant. The hepatic CYP2A5 mRNA level in group 2 was less than that of group 1, but this was not statistically significant (Fig. 3). 
Table III. Final body and relative organ weights (Experiment 2).

\begin{tabular}{|c|c|c|c|c|c|c|}
\hline \multirow[b]{2}{*}{ Group } & \multirow[b]{2}{*}{ Treatment } & \multirow[b]{2}{*}{ No. mice } & \multirow[b]{2}{*}{$\begin{array}{l}\text { Final body weight } \\
(\mathrm{g})\end{array}$} & \multicolumn{3}{|c|}{ Relative organ weight } \\
\hline & & & & $\begin{array}{l}\text { Lung } \\
(\mathrm{g} \%)\end{array}$ & $\begin{array}{l}\text { Liver } \\
(\mathrm{g} \%)\end{array}$ & $\begin{array}{l}\text { Kidney } \\
(\mathrm{g} \%)\end{array}$ \\
\hline 1 & NNK alone & 27 & $28.72 \pm 3.41^{\mathrm{a}}$ & $0.76 \pm 0.10$ & $4.02 \pm 0.33$ & $0.91 \pm 0.09$ \\
\hline 2 & $\mathrm{NNK} \rightarrow \rightarrow 100 \mathrm{ppm} 8-\mathrm{MOP}$ & 27 & $32.22 \pm 3.80^{\mathrm{b}}$ & $0.67 \pm 0.10^{\mathrm{b}}$ & $3.75 \pm 0.32$ & $0.87 \pm 0.10$ \\
\hline 3 & 100 ppm 8-MOP & 24 & $33.64 \pm 4.27^{\mathrm{c}}$ & $0.59 \pm 0.13^{c}$ & $3.68 \pm 0.51^{b}$ & $0.88 \pm 0.12$ \\
\hline 4 & Basal diet & 25 & $30.80 \pm 4.62$ & $0.67 \pm 0.12^{\mathrm{b}}$ & $3.89 \pm 0.46$ & $0.91 \pm 0.13$ \\
\hline
\end{tabular}

${ }^{\mathrm{a}}$ Mean $\pm \mathrm{SD}$. ${ }^{\mathrm{b} S i g n i f i c a n t l y ~ d i f f e r e n t ~ f r o m ~ g r o u p ~} 1(\mathrm{P}<0.05)$. ${ }^{\mathrm{c}}$ Significantly different from group $1(\mathrm{P}<0.01)$.

Table IV. Incidence and multiplicity of NNK-induced pathological lung lesions in A/J mice treated with 8-MOP during progression phase.

\begin{tabular}{lccccccc}
\hline Group & Treatment & No. mice & Incidence $(\%)$ & Hyperplasia & Adenoma & Adenocarcinoma & Total \\
\hline 1 & NNK alone & 27 & 100 & $1.59 \pm 1.45^{\mathrm{a}}$ & $4.74 \pm 2.60$ & $0.44 \pm 0.75$ & $6.78 \pm 3.77$ \\
2 & NNK $\rightarrow \rightarrow 100$ ppm 8-MOP & 27 & 100 & $1.52 \pm 1.97$ & $5.37 \pm 2.44$ & $0.52 \pm 0.64$ & $7.31 \pm 2.86$ \\
3 & 100 ppm 8-MOP & 24 & 33 & $0.17 \pm 0.64$ & $0.25 \pm 0.44$ & 0 & $0.42 \pm 0.72$ \\
4 & Basal diet & 25 & 48 & $0.20 \pm 0.65$ & $0.44 \pm 0.65$ & 0 & $0.64 \pm 0.81$ \\
\hline
\end{tabular}

${ }^{\mathrm{a}}$ Mean $\pm \mathrm{SD}$.
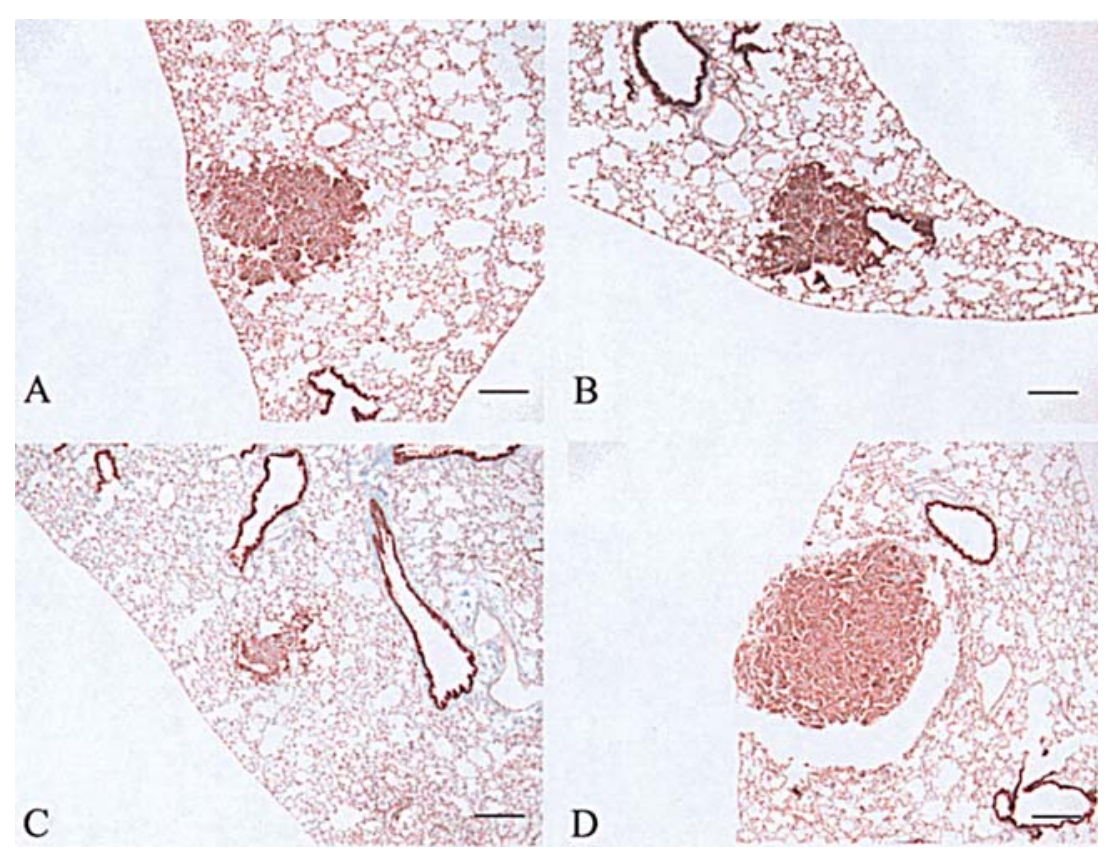

B

Figure 4. Immunohistochemical examination of the expression of CYP2A in adenomas induced by NNK. (A) NNK alone; (B) NNK $\rightarrow 100$ ppm 8-MOP; (C) $100 \mathrm{ppm} 8-\mathrm{MOP}$ and (D) basal diet; Bars, $200 \mu \mathrm{m}$.

Immunohistochemical analysis of CYP2A protein revealed overexpression in all lung adenomas, with or without 8-MOP and/or NNK treatment (Fig. 4).

Experiment 2. Body weight gain was accelerated after starting 8-MOP. Compared with group 1, final body weights showed a significant increase in groups 2 and 3 (Table III). However, average food intakes were increased in the 8-MOP administered groups. Relative lung and liver weights were significantly decreased in the 8-MOP group 2 when compared with group 1, but no histopathological changes were observed in the liver or kidney attributable to toxicity. 
Hyperplasias, adenomas, or adenocarcinomas developed in the lungs of mice in groups 1-4. Adenocarcinomas were recognized in NNK-treated groups. The incidence of these lesions in each group is shown in Table IV. The multiplicity of adenomas and adenocarcinomas was slightly increased by dietary feeding of 8-MOP during the progression phase after NNK exposure, although the difference was not statistically significant.

\section{Discussion}

Human CYP2A6 is recognized as being involved in the mutagenic activation of promutagens such as the tobaccospecific nitrosamine, NNK, and our previous report documented high immunoreactivity for CYP2A6 in human lung adenocarcinomas with lymph node metastasis or large tumor size (10). The most potent inactivator of a CYP2A enzyme reported in the literature is 8-MOP, which inactivates CYP2A6 in a time-, concentration- and NADPH-dependent manner, through binding to the apo-protein $(16,17)$. However, chronic 8-MOP administration during the promotion and progression phases here did not influence the development of lung neoplastic lesions after NNK initiation. These results suggest that 8 -MOP is not a candidate chemopreventive agent for promotion or progression stages, despite evidence of efficacy against initiation (12).

8-Methoxypsoralen is a naturally occurring furanocoumarin derivative found in many fruits and vegetables (18), which has found application in the treatment of psoriasis and cutaneous T-cell lymphomas (19-21). Dunnick et al reported no clear dose-idependent toxicity with oral gavage 8-MOP at 25 and $50 \mathrm{mg} / \mathrm{kg}$ /day for 13 weeks in F344/N rats (22). Furthermore, histopathological lesions and body weight effects were not observed with chronic administration of 8-MOP at the same doses for two years. Since the 8-MOP intake in the present experiments was 10.7-11.6 (promotion phase) and 9.25-9.89 (progression phase) $\mathrm{mg} / \mathrm{kg}$ body weight/day, our results are consistent with the previous report. Although the reason for the body weight increment in our study was unclear, it might have slightly increased the number of lung nodules and the tumor incidence.

We did not obtain any evidence that 8-MOP inhibits hepatic mRNA expression of CYP2A5. Takeuchi et al reported clear dose response inhibitory effects of 8-MOP pretreatment on NNK-induced lung tumorigenesis in female $\mathrm{A} / \mathrm{J}$ mice, but this appeared due to inhibition of enzyme activity of CYP2A4 and CYP2A5, rather than their gene expression (11). Whether there might be variation in relative activity of the CYP2A protein with 8-MOP treatment in mice remains to be clarified.

The potent and relatively specific inhibition of functional human enzyme CYP2A6 makes 8-MOP a good candidate drug to lower the risk of lung cancer in smokers. Furthermore, inhibition of hepatic CYP2A6 by 8-MOP has been shown to increase plasma nicotine levels and decrease nicotine clearance and metabolism in humans in vivo (23). Therefore, it could potentially decrease tobacco exposure in addicted smokers by reducing the number of cigarettes smoked in order to maintain a steady nicotine level. In addition, inhibition of respiratory tract CYP2A6 could block target tissue metabolic activation of tobacco-specific nitrosamines. Recently, it was reported that inhalation of polyphenon E, 5-lipoxygenase inhibitors and budesonide inhibited chemically-induced pulmonary tumorigenesis in the A/J mouse (24-26). Intratracheal administration of 8-MOP might be able to suppress CYP2A6 activity in the respiratory tract without effects on CYP enzymes in the liver.

In conclusion, the results of this study indicate that the dietary intake of 8 -MOP at $100 \mathrm{ppm}(\sim 10 \mathrm{mg} / \mathrm{kg}$ body weight/day) has no effect on NNK-induced lung tumorigenesis in mice when given during the promotion and progression phases.

\section{Acknowledgements}

The authors would like to thank Ms. Kyoko Hosokawa and Mrs. Sanae Kushida for their technical assistance. This study was supported in part by a Grant-in-Aid from the Ministry of Health, Labor and Welfare, Japan.

\section{References}

1. Boffetta P, Pershagen G, Jockel KH, Forastiere F, Gaborieau V, Heinrich J, Jahn I, Kreuzer M, Merletti F, Nyberg F, Rosch F and Simonato L: Cigar and pipe smoking and lung cancer risk: a multicenter study from Europe. J Natl Cancer Inst 91: 697-701, 1999.

2. Lubin JH and Blot WJ: Assessment of lung cancer risk factors by histologic category. J Natl Cancer Inst 73: 383-389, 1984

3. Travis WD, Travis LB and Devesa SS: Lung cancer. Cancer 75: 191-202, 1995.

4. Hecht SS: Biochemistry, biology, and carcinogenicity of tobacco-specific N-nitrosamines. Chem Res Toxicol 11: 559-603, 1998.

5. Imaida $\mathrm{K}$, Yokohira $\mathrm{M}$ and Kuno $\mathrm{T}$ : Detection of carcinogenic and modifying potentials by test compounds using a mouse lung carcinogenesis bioassay. J Toxicol Pathol 20: 117-123, 2007.

6. Kushida H, Fujita K, Suzuki A, Yamada M, Endo T, Nohmi T and Kamataki T: Metabolic activation of N-alkylnitrosamines in genetically engineered Salmonella typhimurium expressing CYP2E1 or CYP2A6 together with human NADPH-cytochrome $\mathrm{P} 450$ reductase. Carcinogenesis 21: 1227-1232, 2000.

7. Fujieda M, Yamazaki H, Saito T, Kiyotani K, Gyamfi MA, Sakurai M, Dosaka-Akita H, Sawamura Y, Yokota J, Kunitoh H and Kamataki T: Evaluation of CYP2A6 genetic polymorphisms as determinants of smoking behavior and tobacco-related lung cancer risk in male Japanese smokers. Carcinogenesis 25: 2451-2458, 2004.

8. Ariyoshi N, Miyamoto M, Umetsu Y, Kunitoh H, Dosaka-Akita H, Sawamura Y, Yokota J, Nemoto N, Sato K and Kamataki T: Genetic polymorphism of CYP2A6 gene and tobacco-induced lung cancer risk in male smokers. Cancer Epidemiol Biomarkers Prev 11: 890-894, 2002.

9. Matsuda Y, Saoo K, Yamakawa K, Yokohira M, Suzuki S, Kuno T, Kamataki T and Imaida K: Overexpression of CYP2A6 in human colorectal tumors. Cancer Sci 98: 1582-1585, 2007.

10. Matsuda Y, Yamakawa K, Saoo K, Hosokawa K, Yokohira M, Kuno T, Iwai J, Shirai T, Obika K, Kamataki T and Imaida K: CYP2A6 overexpression in human lung cancers correlates with a high malignant status. Oncol Rep 18: 53-57, 2007.

11. Takeuchi H, Saoo K, Matsuda Y, Yokohira M, Yamakawa K, Zeng Y, Miyazaki M, Fujieda M, Kamataki T and Imaida K: Dose dependent inhibitory effects of dietary 8-methoxypsoralen on NNK-induced lung tumorigenesis in female A/J mice. Cancer Lett 234: 232-238, 2006.

12. Takeuchi H, Saoo K, Yokohira M, Ikeda M, Maeta H, Miyazaki M, Yamazaki H, Kamataki $\mathrm{T}$ and Imaida $\mathrm{K}$ : Pretreatment with 8-methoxypsoralen, a potent human CYP2A6 inhibitor, strongly inhibits lung tumorigenesis induced by 4(methylnitrosamino)-1-(3-pyridyl)-1-butanone in female $\mathrm{A} / \mathrm{J}$ mice. Cancer Res 63: 7581-7583, 2003. 
13. Miyazaki M, Yamazaki H, Takeuchi H, Saoo K, Yokohira M, Masumura K, Nohmi T, Funae Y, Imaida K and Kamataki T: Mechanisms of chemopreventive effects of 8-methoxypsoralen against 4-(methylnitrosamino)-1-(3-pyridyl)-1-butanoneinduced mouse lung adenomas. Carcinogenesis 26: 1947-1955, 2005.

14. Felicia ND, Rekha GK and Murphy SE: Characterization of cytochrome P450 2A4 and 2A5-catalyzed 4-(methylnitrosamino)1-(3-pyridyl)-1-butanone (NNK) metabolism. Arch Biochem Biophys 384: 418-424, 2000.

15. Dungworth DL, Rittinghausen S, Schwartz L, Harkema JR, Hayashi Y, Kittel B, Lewis D, Miller RA, Mohr U, Morgan KT, Rehm S and Slayter MV: Respiratory system and mesothelium. In: International Classification of Rodent Tumors: The Mouse. Mohr U (ed). Springer, Heidelberg, pp87-137, 2001.

16. Koenigs LL, Peter RM, Thompson SJ, Rettie AE and Trager WF: Mechanism-based inactivation of human liver cytochrome P450 2A6 by 8-methoxypsoralen. Drug Metab Dispos 25: 1407-1415, 1997.

17. Koenigs LL and Trager WF: Mechanism-based inactivation of P450 2A6 by furanocoumarins. Biochemistry 37: 10047-10061, 1998.

18. Scott BR, Pathak MA and Mohn GR: Molecular and genetic basis of furocoumarin reactions. Mutat Res 39: 29-74, 1976.

19. Anderson TF and Voorhees JJ: Psoralen photochemotherapy of cutaneous disorders. Annu Rev Pharmacol Toxicol 20: 235-257, 1980.

20. Parrish JA, Fitzpatrick TB, Tanenbaum L and Pathak MA: Photochemotherapy of psoriasis with oral methoxsalen and longwave ultraviolet light. N Engl J Med 291: 1207-1211, 1974.
21. Edelson R, Berger C, Gasparro F, Jegasothy B, Heald P, Wintroub B, Vonderheid E, Knobler R, Wolff K, Plewig G, et al: Treatment of cutaneous T-cell lymphoma by extracorporeal photochemotherapy. Preliminary results. N Engl J Med 316: 297-303, 1987.

22. Dunnick JK and Elwell MR: Toxicity studies of amphetamine sulfate, ampicillin trihydrate, codeine, 8-methoxypsoralen, alpha-methyldopa, penicillin VK and propantheline bromide in rats and mice. Toxicology 56: 123-136, 1989.

23. Sellers EM, Ramamoorthy Y, Zeman MV, Djordjevic MV and Tyndale RF: The effect of methoxsalen on nicotine and 4(methylnitrosamino)-1-(3-pyridyl)-1-butanone (NNK) metabolism in vivo. Nicotine Tob Res 5: 891-899, 2003

24. Wattenberg LW, Wiedmann TS, Estensen RD, Zimmerman CL, Steele VE and Kelloff GJ: Chemoprevention of pulmonary carcinogenesis by aerosolized budesonide in female A/J mice. Cancer Res 57: 5489-5492, 1997.

25. Yan Y, Cook J, McQuillan J, Zhang G, Hitzman CJ, Wang Y, Wiedmann TS and You M: Chemopreventive effect of aerosolized polyphenon $\mathrm{E}$ on lung tumorigenesis in $\mathrm{A} / \mathrm{J}$ mice. Neoplasia 9: 401-405, 2007.

26. Myrdal PB, Karlage K, Kuehl PJ, Angersbach BS, Merrill BA and Wightman PD: Effects of novel 5-lipoxygenase inhibitors on the incidence of pulmonary adenomas in the A/J murine model when administered via nose-only inhalation. Carcinogenesis 28: 957-961, 2007. 